A Sufi-Jewish Dialogue 
JEWISH CULTURE AND CONTEXTS

Published in association with the Center for Advanced Judaic Studies of the University of Pennsylvania

David B. Ruderman, Series Editor

Advisory Board

Richard I. Cohen

Moshe Idel

Alan Mintz

Deborah Dash Moore

Ada Rapoport-Albert

Michael Swartz

A complete list of books in the series is available from the publisher. 


\section{A Sufi-Jewish Dialogue}

Philosophy and Mysticism in Bahya Ibn Paqūda's Duties of the Heart

D I A N A O B E L

\section{PENN}

University of Pennsylvania Press

Philadelphia 
Copyright $(2007$ University of Pennsylvania Press

All rights reserved

Printed in the United States of America on acid-free paper

$\begin{array}{llllllllll}10 & 9 & 8 & 7 & 6 & 5 & 4 & 3 & 2 & 1\end{array}$

Published by

University of Pennsylvania Press

Philadelphia, Pennsylvania 19104-4112

Library of Congress Cataloging-in-Publication Data

Lobel, Diana.

A Sufi-Jewish dialogue : philosophy and mysticism in Bahya Ibn Paqūda's

Duties of the heart / Diana Lobel.

p. $\mathrm{cm}$.-(Jewish culture and contexts)

Includes bibliographical references and index.

ISBN-13: 978-0-8122-3953-9

ISBN-10: 0-8122-3953-9 (alk. paper)

1. Bahya ben Joseph ibn Pakūda, Ilth cent. Hidayāh ilā farā’id al-qulūb.

2. Jewish ethics-Early works to 1800. 3. Bahya ben Joseph ibn Pakūda, 1 lth cent.Knowledge-Sufism. 4. Judaism-Relations--Islam. 5. Sufism. I. Title.

II. Series.

BJ 1287.B23H4935 2006

$296.3^{\prime} 6-\mathrm{dc} 22$

2006042181 
For Reb Moshe Holcer, z"1

And for Albert, Francine, and Janet Lobel

You have taught me-each in a unique waythe meaning of duties of the heart 
